American Journal of Economics and Business Administration 2 (2): 179-184, 2010

ISSN 1945-5488

(C) 2010 Science Publications

\title{
e-Choupal: Hope or Hype?
}

\author{
Neeraj Dangi and Harjit Singh \\ Department of Management, Institute of Management Education, \\ Sahibabad (Ghaziabad), India
}

\begin{abstract}
Problem statement: This case looked at the cost benefit factor of e-Choupal model in rural India from socio-economic perspective since it is being projected as one of the models of rural empowerment. Questions were raised whether its growth both horizontally and vertically might be detrimental to sustainability of traditional agrarian economy. It also examined the role of ICT and government policies in this context. Approach: The study examined the above mentioned issues from the context of rural India. Empirical literature was referred to build a link between various rural issues and eChoupal. Results: e-Choupal model may not be leading towards a holistic development since the individual income increase of participating members may be at the expense of non-participating members of the rural commune. Conclusion: The results indicated that the present modus operandi of e-Choupal may perhaps lead to further rural consolidation through corporatization rather than rural empowerment.
\end{abstract}

Key words: Rural India, agrarian economy, Information and Communication Technologies (ICT), socio-economic development, e-Choupal, supply chain

\section{INTRODUCTION}

"India lives in villages." This axiom is as true today as it was 60 years ago. Agriculture has been one of the fundamental foundations of the Indian economy, as it accounts for $23 \%$ of the Gross Domestic Product (GDP) and feeds a billion people and employs over $65 \%$ of the workforce (Kothari, 1992; 1994; Sehgal et al., 1992; Ramakrishnan, 1992). Despite a steady decline of its share in the GDP, it is still the largest economic sector and plays a significant role in the overall socio-economic development of India.

In reality, the role of agriculture in India has been not just to produce food but to sustain and contribute towards overall socio-economic development in rural societies. Overregulation of agriculture along with promotion of unsustainable high input technologies in tiny, fragmented unproductive landholdings has increased costs, price risks and uncertainty. The agricultural system has traditionally been unfair to farmers. Farmers by law cannot trade directly with consumers and have to route their produce through traders at a local, government-mandated marketplace, called a mandi. Farmers have only a rough idea of price trends and have to acknowledge the price offered to them at auctions on the day they bring their grain to the mandi. As a result, traders are well positioned to exploit both farmers and buyers through practices that sustain system-wide inefficiencies.
Traditional Indian agriculture: Role in rural sustenance and challenges it faces: The spectacular story of Indian agriculture is known throughout the world for its multi-functional success in generating employment, livelihood, food, nutritional and ecological security besides its cultural significance in our customs and traditions.

With arable land area of about 168 million ha, India ranks second only to the US in size of agriculture. India has $52 \%$ of cultivable land with varied climates and soils affording scope for much diversity in agriculture. India is characterized by a complex mosaic of distinct agro-ecosystems, differentiated by their climatic, soil, geological, vegetational and other natural features. It is within this diversity of habitats that an amazing variety of crops and livestock has developed over the millennia of Indian farming (Kothari, 1992; 1994; Sahai, 1993; Menon, 2007).

The Indian region is in fact one of the world's eight centers of crop plant origin. At least 166 crop species and 320 wild relatives of crops have originated here (Kothari, 1992; 1994; Menon, 2007). But it is the genetic diversity within each species which is even more mind-boggling. For example one species of mango has diversified into over 1000 varieties of varying sizes (Kothari, 1994).

India perhaps also has the world's largest diversity of livestock, with some 30 breeds of cattle, 40 of sheep,

Corresponding Author: Neeraj Dangi, Department of Management, Institute of Management Education, Sahibabad (Ghaziabad), India Tel: 0091-0-99585 06245 
20 of goats and 18 of poultry (Sahai, 1993; Bhat, 1994; Kothari, 1994).

Over generations, Indian farmers have continuously adapted and modified the rich genetic material available to them from nature. The diversity of crops and livestock is the result of millenniums of deliberate selection, planned exposure to a range of natural conditions, field-level cross-breeding and other experiments conducted by farmers. In other words, a single wild species of rice has diversified into 50,000 varieties as a result of the ingenuity and innovative skills of the farming communities (Kothari, 1992; 1994). Different crop varieties and livestock breeds were adapted for diverse local conditions of growth and survival that were available in the country. The diversity is spread over both time (seasonal) and space (geographical) within the same field and both within and between species. Adaptation to localized environments has only been one mechanism or reason for diversification.

More than mere physical adaptation, a host of economic, cultural, religious and survival factors have played a role in this diversification. For instance, Warli tribes of the West Indian state of Maharashtra have grown a great diversity of rice for different water and soil needs, varying maturity periods, resistance to different diseases and various cultural events (Kothari, 1994) Several varieties of rice and other crops were grown in many parts of India just for use during festivals, marriages, or other auspicious occasions. Yet others were grown for their taste, color, or smell.

The stability of a bio-diverse agriculture is perhaps its most important characteristic, as recorded from many parts of the world. Many times, the practice involves the sowing of a mixture of crops into a single plot of land to obtain optimal and sustained yields. Since maturity periods of these crops vary, different crops are harvested at different times, helping to retain soil moisture and providing a constant supply of food. Fertility is continuously recharged by the use of leguminous plants like pulses.

The changes and its cost: Agricultural schemes have also supported farm and crop homogenization. An earlier complex mosaic of diverse micro-habitats is being transformed into now vast stretches of uniform agricultural landscape. Intercropping is replaced by mono-cropping, a wide diversity of species is replaced by a handful of profitable ones and the great genetic diversity within the same crop species is replaced by a narrow genetic range of financially lucrative varieties. These features result in an increasing dependence of the farmer on the industry-dominated market and government. Virtually everything that is required for farming, except land and labor, is now obtained from outside: seeds, irrigation, fertilizers, pesticides, credit. And despite huge subsidies for these inputs, as also support prices and the like, an increasing number of farmers are facing an economic treadmill, spending more and more to achieve the same output.

Officially, green revolution technologies have been credited for improving quantitatively, India's agricultural productivity making it a net exporter of a variety of food grains. The overall gain in increased productivity has not translated into an improvement of the overall rural agrarian economy, especially farmers. The reasons include stress on quantity rather than quality, focus on maximum yield rather than optimum yield, promotion of a few selected crops with a narrow genetic base, instead of a wide genetic band among varied crop varieties (to satisfy food needs). In effect, agriculture has been commoditized to look as like any other industry. Indeed, the recent thrust towards agroexports and agro-product processing is likely to intensify this destruction. There is a certain homogenizing logic to global markets, which demands standardized, easy to package and easy to price goods. Incentives are likely to increase for farmers to grow such produce for export, rather than for achieving localized self-sufficiency, at least in food grains. In other words, this enhances the trend towards converting food cropping lands to short-term cash cropping.

Conventional post-harvest supply chain: Typically, after harvest, farmers bring their produce to mandis (regional market yards) in small multiple lots throughout the year, where it is auctioned to traders and agents of processing companies in an open outcry method. However, despite the government regulating these market yards, there is lack in transparency in prices and cheating in weighing. Also many intermediaries carry out this whole activity, each one acting as a principal with the next leg in the transaction chain adding his/her profit margin at each stage, thereby increasing the overall cost in the supply chain. The international Business Division of ITC started the new initiative namely e-Choupal (village meeting place on an electronic platform).

\section{MATERIALS AND METHODS}

The case study was based on secondary data sources in print and online media from corporate, government and NGOs sources.

ITC and e-Choupal: ITC is one of India's foremost private sector companies with a market capitalization 
of nearly US \$ 14 billion and a turnover of over US \$ 5 billion. ITC ranks among India's '10 most valuable (company) brands', in a study conducted by Brand Finance and published by the Economic Times. ITC has a diversified presence in cigarettes, hotels, paperboards and specialty papers, packaging, agri-business, packaged foods and confectionery, information technology, branded apparel, personal care, stationery and other FMCG products. ITC is a major exporter of soya bean. It used to buy soya bean mainly from local markets. This created the problem of poor quality produce; need to handle a large variety and high cost of intermediation (Bowonder et al., 2007; Prahalad, 2006; ITC, 2007).

ITC's Agri Business Division conceived e-Choupal as a more efficient supply chain aimed at delivering value to its customers around the world on a sustainable basis. e-Choupal is an initiative to link directly with rural farmers for procurement of agricultural/ aquaculture produce like soybeans, wheat, coffee and prawns. It offers farmers all the information, products and services they need to enhance farm productivity improve farm-gate price realization and cut transaction costs. Farmers can access the latest local and global information on weather, scientific farming practices as well as marker prices at the village itself through a portal. It also facilitates supply of high quality farm inputs as well as purchase of commodities at their doorstep. Another path-breaking initiative-the 'Choupal Pradarshan Khet', brings the benefits of agricultural best practices to small and marginal farmers (Bowonder et al., 2007; Prahalad, 2006; ITC, 2007).

Business model in practice: Village internet kiosks managed by farmers-called sanchalaks (operators)themselves, enable the agricultural community access ready information in their local language on the weather and market prices, disseminate knowledge on scientific farm practices and risk management, facilitate the sale of farm inputs (now with embedded knowledge) and purchase farm produce from the farmers' doorsteps (decision making is now information-based) (Bowonder et al., 2007; Prahalad, 2006; ITC, 2007; Kumar, 2004; Best and Maclay, 2002). Real-time information and customized knowledge provided by 'eChoupal' enhance the ability of farmers to take decisions and align their farm output with market demand and secure quality and productivity. As a direct marketing channel, virtually linked to the 'mandi' (market yard) system for price discovery, 'e-Choupal' eliminates wasteful intermediation and multiple handling. Thereby it significantly reduces transaction costs. They also use the e-Choupal to order seeds, fertilizers and other products such as consumer goods from ITC or its partners, at prices lower than those available from village traders; the sanchalak typically aggregates the village demand for these products and transmits the order to an ITC representative. At harvest time, ITC offers to buy the crop directly from any farmer at the previous day's closing price; the farmer then transports his crop to an ITC processing center, where the crop is weighed electronically and assessed for quality.

The farmer is then paid for the crop and a transport fee. "Bonus points," which are exchangeable for products that ITC sells, are given for crops with quality above the norm. In this way, the e-Choupal system bypasses the government-mandated trading mandis. Farmers selling directly to ITC through an e-Choupal typically receive a higher price for their crops than they would receive through the mandi system, on average about $2.5 \%$ higher (about \$US 6 ton $^{-1}$ ). Due to eChoupal there has been a dramatic shift towards soy plantation (from 50-90\% in some regions). Simultaneously, the volume of soy marketed through mandis has dropped by as much as half. On the contrary, ITC has benefited through lower procurement costs and having more direct control over the quality of produce. The system also provides direct access to the farmer and to information about conditions on the ground, improving planning and building relationships that increase security of supply. The company reports that it recovers its equipment costs from an e-Choupal in the first year of operation and that the venture as a whole is profitable. The system also links farmers and their families to the world by tracking prices on the Chicago Board of Trade and village children using computers for schoolwork, games and to obtain and print outs. The result is a significant step towards rural development (Bowonder et al., 2007; Prahalad, 2006; Kumar, 2004).

e-Choupal value chain: Two way conduit: ITC contends that such a market-led business model can enhance the competitiveness of Indian agriculture and trigger a virtuous cycle of higher productivity, higher incomes and enlarged capacity for farmer risk management, larger investments and higher quality produce. Further, a growth in rural incomes will also unleash the latent demand for industrial goods so necessary for the continued growth of the Indian economy. This initiative also creates a direct supply chain to ITC, which buys the agricultural produce directly from farmers. ITC ensures a secure supply of produce to itself through this and also lowers its procurement costs by eliminating traders and 
intermediaries. ITC also uses the e-Choupal as a medium to advertise its consumer products where farmers can buy ITC's products (Bowonder et al., 2007; Prahalad, 2006).

Current status: Launched in June 2000, 'e-Choupal', has already become the largest initiative among all Internet-based interventions in rural India. 'e-Choupal' services today reach out to over four million farmers growing a range of crops-soybean, coffee, maize, wheat, rice, pulses, shrimp-in over 40,000 villages through 6,500 kiosks across ten states (Madhya Pradesh, Haryana, Uttarakhand, Karnataka Andhra Pradesh, Uttar Pradesh, Rajasthan, Maharashtra, Kerala and Tamil Nadu) (ITC, 2007).

\section{RESULTS}

ICT of e-Choupal: A false 'win-win' solution in a world of unequal actors: One of the greatest opportunities offered by ICTs has been the enhanced possibility for collaboration among different actors for specific development goals (Benkler, 2006; Prahalad, 2006). Widely acclaimed as an ICT success story, it typifies the complete corporatization of the social enterprise model. An initiative seeking to become the Wal-Mart of rural India, e-Choupal is a gateway to an expanding spectrum of commodities leaving farms and also selling to rural India urban oriented goods and services like FMCG, consumer durables and insurance services (Gurumurthy, 2009; Prahalad, 2006). Based on a business model providing connectivity and services to a closed network of farmers through an entrepreneur whose role, interestingly, is projected by ITC as a "public office", e-Choupal exemplifies the win-win problematique (Gurumurthy, 2009; Prahalad, 2006).

However a closer study of the model, from a development perspective, unpacking the socio-politics of the e-Choupal ecosystem, indicates a monopolistic control over the entire local agriculture ecology by a transnational corporation through the use of a captive ICT infrastructure, with minimal regulation and competition. The e-Choupal hubs serve as sales outlets for agriculture and other products and services. Cutting off alternative systems, local middlemen and government services, e-Choupal locks in a large number of farmers into its network. While the project has resulted in some increase in rural agricultural incomes through privatization driven efficiency improvements in the supply chain, e-Choupal underscores 'trickle-down' and individual enterprise at the village levels (Gurumurthy, 2009; Prahalad, 2006). The average village shopkeeper/entrepreneur is bound to get affected as local demand for goods and services shifts to ITC and Choupal sagars. Needless to mention livelihood of traders/middlemen whose livelihood has been squelched through this model.

Further, the 'DNA' profile of the farmers acquired during the registration of e-Choupals has allowed ITC to determine and understand their buying behavior very closely. This has allowed targeting, positioning and delivering goods and services to match their needs and wants continuously, succinctly called Customer Relationship Management (CRM) in marketing parlance. This makes them more vulnerable to a shift from the present more or less sustainable existence to materialistic consumerism. Little awareness of their (farmer's) rights may not guarantee total protection of the database and its unethical usage. This is where the government is expected to protect its citizens from such transactions. However, the government has been changing slowly but surely towards a free market economy.

Role of Government: reorienting socio-economic paradigm: At a time when thousands of farmers have committed suicide in the past few years throughout the country, the government's intention of introducing future trading in rice, wheat and other commodities shows complete bankruptcy in finding alternatives (Menon, 2007; Prahalad, 2006; Shiva, 2004; 2006; Srivastava, 2006; Brundtland, 1987). In India, the average land holding size is 1.47 ha and less than $10 \%$ of the farming population has land holdings exceeding 4 ha. To expect farmers, who continue to survive against all odds year after year, to go online and trade seems to be the wild imagination of a stockbroker.

Even in America, it is not farmers who trade at the stock markets. It is the traders, which do that. If only future trading was a viable mechanism for raising income across the board for all farmers by providing efficient management of price risks through hedging, there was no need for rich countries in European Union and North America to shell out monumental subsidies for agriculture. If American farmers, with the level of education and the size of landholdings, do not find future trading to be helpful, it is strange how the Indian government is promoting it as a savior for the farming community.

It is known that the government is slowly withdrawing from food procurement citing the unwieldy procurement structure and inefficiencies in the system as the main reason. Food procurement however was an essential measure to provide an assured market to farmers (Shiva, 2004; 2006). By withdrawing from food procurement, it is obvious that farmers are 
being penalized for the inefficiency of Food Corporation of India (FCI). The emergence of 'eChoupal' is also timed with the withdrawal of safety nets like changes in the Agricultural Produce Marketing Committee Acts (APMC) which were designed to ensure farmers get a proper price. The markets and mandis were governed by elected market committees with predominance of agriculturalists for the management of the market. By having many traders and a ceiling on volume traded, monopolies could not emerge in mandis. In effect, the model act is an act to legalize exploitation by removing all regulations on price and volume of purchase instead of proper implementation of laws. The model act promotes creation of monopolistic buying by agri-businesses. This is how ITC has set up its e-Choupals against which there are protests and statewide strikes (Ravichandran, 2008; Shiva, 2004; 2006).

\section{DISCUSSION}

This study examines the inter-linkages of various aspects of a rural agrarian economy in India and its probable effect by e-Choupal. It explains how social and ecological areas are also important besides economic prosperity for long term sustainability and harmony in rural India. The non-participating members in the agricultural value chain may be losing out due to changing environment at local and national level. The policies appear to be profit oriented rather than promoting long term well being and welfare of people associated with agriculture. Sustainability stands three pillars of economic viability, social relevancy. And they can be effectively woven by laying emphasis on the human element.

\section{CONCLUSION}

Empowerment is difficult to establish especially when you consider various social parameters which cannot be quantified with ease. Relying mostly on economic improvement as a measure of development ignoring social, cultural and ecological domains is a reductionist approach. Although e-Choupal model demonstrates that a large corporation can play a major role in increasing the efficiency of an agricultural system and create a platform that benefits farmers. Still it may not be considered a model of inclusive growth as till now it is has not holistically addressed other issues like social and ecological, which apparently play a significant role in rural life and to some extent the agrarian economy in a developing country like India. In addition benefits accrued to ITC (e-Choupal's incubator) may outweigh the benefits to rural society.
Questions are also raised regarding the scalability of the project geographically as well as in terms of crop diversity. However further empirical studies are required to determine e-Choupal's effect on rural economy in the long term and whether it is leading to rural empowerment as professed.

\section{REFERENCES}

Best, M.L. and C.M. Maclay, 2002. Community Internet Access in Rural Areas: Solving the Economic Sustainability Puzzle. In: The Global Information Technology Report 2001-2002: Readiness for the Networked World, Kirkman, G., J. Sachs, K. Schwab and P. Cornelius (Eds.)., 1st Edn., Oxford University Press, USA, ISBN: 9780195152586, pp: 76-88.

Benkler, Y., 2006. The Wealth of Networks: How Social Production Transforms Markets and Freedom. 1st Edn., Yale University Press, New Haven, ISBN: 0-300-11056-1, pp: 515.

Bhat, P.N., 1994. Conservation of animal genetic resources in India. http://www.fao.org/docrep/003/x6526e/X6526E11.htm

Brundtland, G., 1987. Our Common Future: The World Commission on Environment and Development. 1st Edn., Oxford University Press, Oxford, ISBN: 0195531914, pp: 444.

Bowonder, B., V. Gupta and A. Singh, 2007. Developing a rural market e-hub: The case study of e-Choupal experience of ITC. http://planningcommission.nic.in/reports/sereport/s er/stdy_ict/4_e-choupal\%20.pdf

Gurumurthy, A., 2009. Social enterprise to mobiles-the curious case of a propped up ICTD theory. http://publius.cc/social_enterprise_mobiles_\%E2\% 80\%93_curious_case_propped_ictd_theory/091709

Kothari, A., 1992. Reviving diversity in India's agriculture. http://www.grain.org/seedling/?id=393

Kothari, A., 1994. Conserving Life: Implications of the Biodiversity Convention for India. 2nd Edn., Kalpavriksh, New Delhi, pp: 95.

Kumar, R., 2004. eChoupals: A study on the financial sustainability of village internet centers in rural Madhya Pradesh. Inform. Technol. Int. Dev. Arch., 2: 45-74. DOI: 10.1162/1544752043971161

Menon, R., 2007. Danger signals for India's biodiversity. http://www.boloji.com/environment/102.htm

Prahalad, C.K., 2006. The Fortune at the Bottom of the Pyramid: Eradicating Poverty through Profits. 1st Edn., Wharton School Publishing, New Jersey, ISBN: 0131877291, pp: 273. 
Ramakrishnan, P.S., 1992. Shifting Agriculture and Sustainable Development: An Interdisciplinary Study from Northeast India, Man and Biosphere Series. 1st Edn., Vol. 10, UNESCO and Parthenon Publishing, Caernforth, Lancs, U.K., pp: 424.

Ravichandran, R., 2008. ECA may hamper ITC's 'eChoupal' network: Deveshwar. http://www.financialexpress.com/news/eca-mayhamper-itcs-echoupal-network-deveshwar/344190/

Sahai, R., 1993. Animal Genetic Resources Scenario of India. Proceeding of the National Seminar on Animal Genetic Resources and their Conservation, Apr. 22-23, Karnal, National Institute of Animal Genetics, National Bureau of Animal Genetic Resources and Nature Conservators, Karnal.

Sehgal, J.L., D.K. Mandal, C. Mandal and S. Vedivelu, 1992. Agro-Ecological Regions of India. 2nd Edn., National Bureau of Soil Survey and Land Use Planning, Indian Council of Agricultural Research, New Delhi and Oxford and IBH Pub. Co, ISBN: 8185460159, pp: 112.
Shiva, V., 2004. An open letter to the finance minister. http://www.outlookindia.com/article.aspx?224354

Shiva, V., 2006. The great grain robbery by agribusiness MNC's: A recipe for more farmers' suicides, more hunger and more disease. http://www.worldproutassembly.org/archives/2006 /06/the_great_grain.html

Srivastava, S., 2006. Pasture plazas. http://www.outlookindia.com/article.aspx?232470

ITC., 2007. ITC: e-Choupal: Let's put India first. http://www.itcportal.com/ruraldevelopment/echoupal.htm 